ENTREPRENEURSHIP AND SUSTAINABILITY ISSUES

ISSN 2345-0282 (online) http://jssidoi.org/jesi/

2021 Volume 8 Number 3 (March)

http://doi.org/10.9770/jesi.2021.8.3(6)

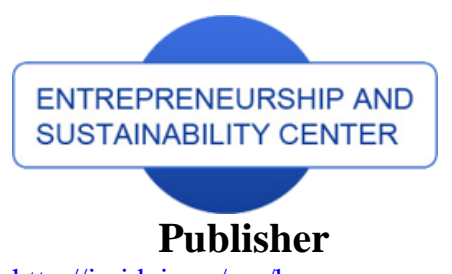

enterprise

europe

network

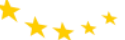

Business Support on Your Doorstep
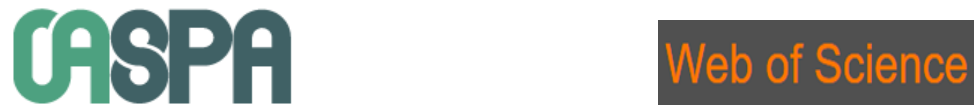

http://jssidoi.org/esc/home

I) Clarivate

Analytics

\title{
MODERN TRENDS IN THE ECONOMIC DIFFERENCES BETWEEN COUNTRIES AND WITHIN THEM: COMPARISON OF THE WORLD AND THE EUROPEAN UNION
}

\author{
Vera Komarova ${ }^{1}$, Natalya Selivanova-Fyodorova ${ }^{2}$, Oksana Ruza ${ }^{3}$, \\ Jerzy Kazmierczyk ${ }^{4}$, Iluta Arbidane ${ }^{5}$ \\ ${ }^{1,3}$ Daugavpils University, Parades Str. 1, Daugavpils, LV-5401, Latvia \\ ${ }^{2}$ RISEBA University of Applied Sciences, Meza Str. 3, Riga, LV-1048, Latvia \\ ${ }^{4}$ Poznan University of Economics and Business, Niepodległosci Avenue 10, Poznan, 61-875, Poland \\ ${ }^{5}$ Rezekne Academy of Technologies, Atbrivoshanas Avenue 115, Rezekne, LV-4601, Latvia \\ E-mails: ${ }^{1}$ vera.komarova@du.lv; ${ }^{2}$ nsel15@inbox.lv, ${ }^{3}$ oksana.ruza@du.lv; \\ ${ }^{4}$ jerzy.kazmierczyk@ue.poznan.pl; ${ }^{5}$ iluta.arbidane@inbox.lv
}

Received 11 September 2020; accepted 26 November 2020; published 30 March 2021

\begin{abstract}
This article aims to test empirically two popular hypotheses about territorial economic differences in the modern world. According to the first hypothesis, economic differences between countries in the modern world are not as large as regions' differences within countries. According to the second hypothesis, the decline in the degree of economic differences between countries is due to the relatively faster economic development of capital regions. Investigation of the economic differences on various territorial levels realized applying the method of comparing the coefficient of variation of the income of the population. The source of the empirical data for this research is the Sub-national Human Development Index (SHDI) database created by the Netherlands Institute for Management Research of the Radboud University, which contains such indicator as Income index of SHDI in the inner regions of 161 countries in the world for the period from 2000 to 2017. A comparison of economic differences at different territorial levels revealed that in the $21^{\text {st }}$ century, neither in the world as a whole nor in the EU regions' differences within countries are higher than differences between countries. However, starting with 2015 the economic differences between inner regions of the EU countries began to outweigh the economic differences between countries themselves, and this is the specifics of the European Union. In the $21^{\text {st }}$ century, both inter-country and intra-country regional economic differences in the EU countries are significantly lower than in the world as a whole. The economic importance of non-capital regions is gradually increasing in the EU, although for the time being the EU (and probably the world as a whole) still characterized by the economic growth, which is based mainly at the expense of capital regions.
\end{abstract}

Keywords: economic differences; world; European Union; capital regions; coefficient of variation.

Reference to this paper should be made as follows: Komarova, V., Selivanova-Fyodorova, N., Ruza, O., Kazmierczyk, J., Arbidane, I. (2021). Modern trends in the economic differences between countries and within them: comparison of the world and the European Union. Entrepreneurship and Sustainability Issues, 8(3), 110-121. http://doi.org/10.9770/jesi.2020.8.3(6)

JEL Classifications: O47; R11; C33 


\section{ENTREPRENEURSHIP AND SUSTAINABILITY ISSUES}

ISSN 2345-0282 (online) http://jssidoi.org/jesi/

2021 Volume 8 Number 3 (March)

http://doi.org/10.9770/jesi.2021.8.3(6)

Make your research more visible, join the Twitter account of ENTREPRENEURSHIP AND SUSTAINABILITY ISSUES: @Entrepr69728810

\section{Introduction}

Almost all the contemporary researchers of territorial economic development peculiarities address the topic of economic differences in various aspects. The economic differences between territories - countries and regions are studied not only by regional economists (Karwat-Wozniak 2011; Boronenko et al. 2014; Tvaronaviciene 2018; Rivza 2018; Prakash, R Garg, 2019; Okuneviciute-Neverauskiene et al. 2020 and many others). This topic at least, in Latvia, - is elaborated also by geographers within regional and human geography (Krauklis 2000; Krisjane, Bauls 2007; Kule at al. 2010; Berzins 2011), that coincides with the common trends worldwide (Hua, Gu 2001; Kovacs 2004); this happens so because regional economics historically developed from the science of geography and continues closely interacting with itin the framework of regional science, because investigation of the spatial correspondences and mutual relatedness of nature and social processes brings out the common interest field of economic geography and regional economics (Ullman 1958; Isard 1960, 1975; Granberg 1997; Gibbons, Vignoles 2011; Chatterji 2014).

Regarding the economic differences on various territorial levels, some researchers and international organizations revealed that economic differences between countries (inter-country level) are often not so large as the economic differences between regions within these countries (intra-country regional level) (Kim 2008; OECD 2011, 2013, 2016). In many cases the reduction of the degree of economic differences between countries are rather connected with the development of the capital regions (OECD 2016), as the political and economic life of the whole country is concentrated in these regions; this is especially characteristic of Central and East Europe (Kuttor 2009).

Within this research, the authors provide the comparative empirical analysis of the modern trends in the degree of economic differences of the world and EU countries on various territorial levels by comparing coefficients of variation on the inter-country and intra-country regional level, as well as by comparing coefficients of variation between EU countries and their capital regions. The empirical analysis is limited to the beginning of the $21^{\text {st }}$ century (2000-2017). The source of the empirical data for this research is the Sub-national Human Development Index (SHDI) database created by the Netherlands Institute for Management Research of the Radboud University (Radboud University 2020). This database is elaborated on the basis of Human Development Index (HDI) database created by United Nations Development Programme (UNDP) (UNDP 2020). SHDI database contains not only sub-indexes of HDI but also indicators of population's income, school education duration, and newborns' life expectancy in the inner regions of 161 countries in the world.

\section{Theoretical background}

There is quite a lot of research in the scientific literature dedicated to the study and comparison of differences between countries and inner regions (more often - economic differences) in different spatial areas of the world and in different time periods (Sala-i-Martin 1995, 1996; Kanbur et al. 2006). According to the authors, systemic research - from the macro level to the meso level - in this field was carried out by X. Sala-i-Martin. For example, the analysis of the process of differentiation of economic performance indicators (by GDP per capita) in 110 countries of the world in the period from 1960 to 1990 showed that the degree of economic differences between these countries increased steadily during the studied period (Sala-i-Martin 1995). In Europe, X. Sala-i-Martin studied the differences between regions within each country and concluded that "the overall picture shows a decrease in differences between regions over time in each country" (Sala-i-Martin 1995). Nevertheless, the authors did not find in these results a comparison between the degree of differences at the inter-country and intracountry regional level. It means, that the results of abovementioned studies do not suggest precise proof of the 


\section{ENTREPRENEURSHIP AND SUSTAINABILITY ISSUES}

ISSN 2345-0282 (online) http://jssidoi.org/jesi/

2021 Volume 8 Number 3 (March)

http://doi.org/10.9770/jesi.2021.8.3(6)

Make your research more visible, join the Twitter account of ENTREPRENEURSHIP AND SUSTAINABILITY ISSUES: @Entrepr69728810

thesis mentioned in the introduction to this article: economic differences between countries are often not so large as the economic differences between regions within these countries (Kim 2008; OECD 2011, 2013, 2016).

The authors believe that the Organization for Economic Co-operation and Development (OECD) in its analytical reports on regions "OECD Regions at a Glance" emphasizes the comparison of differences at the inter-country and intra-country regional level. For example, with regard to national and regional differences in educational attainment, the OECD notes that differences in the availability of high-educated workforce are mostly observed in different regions of the same country rather than between countries. The largest differences in the availability of workforce with higher education are in the Czech Republic, France, Spain and the United States. For example, in 2008, 16\% of the workforce had completed higher education in West Virginia (United States), compared to 44\% in the District of Columbia (or just Washington) (OECD 2011). Moreover, inequality in household disposable income between regions of Israel, Spain, Turkey and the United States is much higher than inequality between countries themselves (OECD 2016).

The analysis of studies of the differences at the inter-country and intra-country regional level described above shows that it is difficult to compile comparable inequality indicators in many countries and regions, and that there is no international cross-sectional analysis in the scientific literature on inequality issues (Kim 2008). As a result, studies of the economic differences between regions predominantly are comparative studies within some individual countries (Kim 1998; Rodriguez-Pose, Sanchez-Reaza 2005; Kanbur, Zhang 2005; Knight et al. 2006).

There are also attempts in the scientific literature to compare the economic differences at the inter-country and intra-country regional level in developed and developing countries (Kanbur, Venables 2005; Kim 2008). Due to the lack of reliable data in developing countries, population statistics is often based on survey data. The data tend to show a greater degree of regional differences in developing countries, and this could be due to low data quality or a large disproportion in the economic situation of developing countries. For developed countries, despite quite large differences in the degree of regional differentiation between countries, the patterns of industrial localization are quite similar (Kim 2008).

Most importantly, the data on developing countries suggest that the geographical and political factors specific to each developing country may play a significantly greater role in the process of regional differentiation than in developed countries. These differences in the process of intra-country regional differentiation create some difficulties in identifying the causes of territorial inequalities in developing countries. The United Nations University World Institute's for Development Economics project "Spatial Disparities in Human Development", led by R. Kanbur and A.J. Venables, included data on the degree of intra-country regional differences in more than 50 developing countries. Although the content of actual data varied considerably from country to country, it was argued that the degree of regional differences has increased in many developing countries in recent years (Kanbur, Venables 2005).

Data on the degree of intra-country regional differences in developed countries are much more reliable and valid. Despite significant differences, the main driver of regional differentiation in developed countries is geographical differences in industrial concentration. In general, geographical differences in the concentration of industries such as agriculture and mining increase regional differences, as natural resources are unevenly distributed, while most service sectors, especially those serving local markets, tend to reduce differences between regions (Kim 2008). For example, in the United States, traditional low-tech industries, such as textiles, clothing, and tobacco, were much more localized than medium- and high-tech industries, such as electricity, transportation, and so on. Thus, it 


\section{ENTREPRENEURSHIP AND SUSTAINABILITY ISSUES}

ISSN 2345-0282 (online) http://jssidoi.org/jesi/

2021 Volume 8 Number 3 (March)

http://doi.org/10.9770/jesi.2021.8.3(6)

Make your research more visible, join the Twitter account of ENTREPRENEURSHIP AND SUSTAINABILITY ISSUES: @Entrepr69728810

can be argued that the gradual shift of production from low-tech to high-tech industries contributed to a greater dispersion of production over time (Kim 1998) and to decrease in intra-country regional differences.

According to the European Union, Eurostat Regional Yearbook identifies three main features of the process of regional differentiation in Europe, which are fully in line with the results of the above-analyzed studies on the economic differences at the inter-country and intra-country regional level in other parts of the world: 1) very high degree of intra-country regional economic differences by GDP per capita; 2) a geographical profile of the process of regional differentiation has the form of a "center-periphery" model; 3) the growing economic importance of the regions in which the capital cities of the EU Member States are located (Eurostat 2018).

\section{Research objective and methodology}

This article aims to test empirically two popular hypotheses about territorial economic differences in the modern world. According to the first hypothesis, economic differences between countries in the modern world are not as great as regions' differences within countries. According to the second hypothesis, the decline in the degree of economic differences between countries is due to the relatively faster economic development of capital regions, which are the centers of politically and economically highly centralized countries, especially in Central and Eastern Europe (Kuttor 2009).

Further on the authors provide empirical interpretation of the research subject - the economic differences of territories - in order to specify those indicators whereby the process of the economic differentiation of territories and its results could be empirically measured and studied. In the scientific literature, there are mainly two indicators, the differences in which can be considered as economic differences. Firstly, many studies of economic performance of regions and its differences (Dunford 2008; Stankevics et al. 2014; Boronenko et al. 2014; Kolaríkova et al. 2018) use Gross Domestic Product (GDP) per capita indicator to assess the economic differences between territories. Secondly, several studies of the economic inequality among regions (Atkinson 1970; Lubrano 2017), as well as studies of the regional aspect of income differentiation (Lavrinovica, Lavrinenko 2011) use the income of the population for assessment of the economic differences between territories.

A relatively wide range of instruments can be used to measure the degree of territorial differences, such as the Tail index, the Atkinson index, the Gini coefficient, the coefficient of variation and the coefficient of asymmetry (Ruitebeek 1996; Styme, Jackson 2000; Paas, Schlitte 2006; Dunford 2008; Lavrinovich et al. 2012). Following S. Drobishevskiy and A. Iodchin, the authors will use the coefficient of variation in the further empirical analysis. Coefficient of variation as the indicator of the state of differentiation of territories is to be used as it does not depend on the unit of measure of the indicator under analysis (Drobishevskiy et al. 2005; Iodchin 2007).

Thus, in the course of empirical interpretation of the economic differences between territories, the authors separated the indicators of the economic activity per se (GDP per capita and the income of the population) from the indicator of the state of economic differentiation of regions (coefficient of variation). Comparing the coefficients of variation on inter-country and intra-country regional level, the authors will clarify on which territorial level the degree of economic differences is higher.

The Sub-national Human Development Index (SHDI) database for the period from 2000 to 2017 (Radboud University 2020) is used as the source of empirical data, as it contains indicators on the income of the population both in the countries of the world and in their inner regions. It will allow authors to compare the degree of inter- 
ENTREPRENEURSHIP AND SUSTAINABILITY ISSUES

ISSN 2345-0282 (online) http://jssidoi.org/jesi/

2021 Volume 8 Number 3 (March)

http://doi.org/10.9770/jesi.2021.8.3(6)

Make your research more visible, join the Twitter account of ENTREPRENEURSHIP AND SUSTAINABILITY ISSUES: @Entrepr69728810

country and intra-country regional economic differences in the world as a whole and in the European Union. Inner regions of countries within this research are not the normative (e.g. NUTS in the European Union), but analytical or functional subnational regions (Radboud University 2020). In the SHDI database, functional subnational regions are included, and the authors consider it fully acceptable and even relatively more productive for understanding economic reality than comparing normative regions. Moreover, the authors believe that strictly according to the NUTS classification it is not possible to compare territories even within the EU. For example, in Latvia the NUTS1 level - it is a whole country, in Poland - these are 6 regions (and each of them is NUTS1 region) and in Germany there are 16 lands (each of which is a NUTS1 region) (European Commission 2011). Thus, the authors of this study believe that it is useful to use the so-called functional classification of regions in global comparative studies, which examine not only the situation in the EU (Howe, Stabler 1989).

\section{Results and discussion}

Analyzing the results of the empirical research, the authors will try to answer precisely the two central questions of this study: 1) where - in the world as a whole or in the European Union - economic differences between inner regions dominate (if dominate at all) over differences between countries? 2) is the reduction of the degree of economic differences between countries in the world as a whole and in the European Union determined primarily by the growth of capital regions? Data of Table 1, as well as Figures 1 and 2, allows to compare the degree of economic differences between the world and EU countries at the inter-country and intra-country regional levels at the beginning of the $21^{\text {st }}$ century.

Table 1: Degree of economic differences of the world and EU countries on the inter-country and intra-country regional level, coefficient of variation, 2000-2017

\begin{tabular}{|c|c|c|c|c|}
\hline \multirow[b]{2}{*}{ Year } & \multicolumn{2}{|c|}{ World countries, $\mathrm{n}=132$} & \multicolumn{2}{|c|}{ EU countries, $n=26$} \\
\hline & $\begin{array}{c}\text { Degree of } \\
\text { economic differences on } \\
\text { the inter-country level }\end{array}$ & $\begin{array}{c}\text { Mean value of the degree } \\
\text { of economic differences } \\
\text { on the intra-country } \\
\text { regional level }\end{array}$ & $\begin{array}{l}\text { Degree of } \\
\text { economic differences on } \\
\text { the inter-country level }\end{array}$ & $\begin{array}{c}\text { Mean value of the degree } \\
\text { of economic differences } \\
\text { on the intra-country } \\
\text { regional level }\end{array}$ \\
\hline 2000 & 0.287 & 0.079 & 0.089 & 0.053 \\
\hline 2001 & 0.285 & 0.079 & 0.085 & 0.053 \\
\hline 2002 & 0.285 & 0.078 & 0.080 & 0.053 \\
\hline 2003 & 0.286 & 0.078 & 0.077 & 0.053 \\
\hline 2004 & 0.282 & 0.078 & 0.073 & 0.052 \\
\hline 2005 & 0.280 & 0.077 & 0.068 & 0.053 \\
\hline 2006 & 0.279 & 0.076 & 0.066 & 0.053 \\
\hline 2007 & 0.274 & 0.075 & 0.062 & 0.053 \\
\hline 2008 & 0.271 & 0.074 & 0.058 & 0.052 \\
\hline 2009 & 0.267 & 0.074 & 0.058 & 0.054 \\
\hline 2010 & 0.265 & 0.073 & 0.060 & 0.054 \\
\hline 2011 & 0.262 & 0.073 & 0.058 & 0.053 \\
\hline 2012 & 0.258 & 0.072 & 0.057 & 0.053 \\
\hline 2013 & 0.258 & 0.072 & 0.055 & 0.053 \\
\hline 2014 & 0.255 & 0.071 & 0.054 & 0.053 \\
\hline 2015 & 0.256 & 0.071 & 0.053 & 0.053 \\
\hline 2016 & 0.256 & 0.070 & 0.051 & 0.053 \\
\hline 2017 & 0.255 & 0.070 & 0.049 & 0.052 \\
\hline
\end{tabular}

Source: calculated and drawn by the authors according to the data of Radboud University 2020

Note: the name of the indicator under analysis in the data source is: Income index of Subnational Human Development Index (Radboud University 2020) 
ENTREPRENEURSHIP AND SUSTAINABILITY ISSUES

ISSN 2345-0282 (online) http://jssidoi.org/jesi/

2021 Volume 8 Number 3 (March)

http://doi.org/10.9770/jesi.2021.8.3(6)

Make your research more visible, join the Twitter account of ENTREPRENEURSHIP AND SUSTAINABILITY ISSUES: @Entrepr69728810

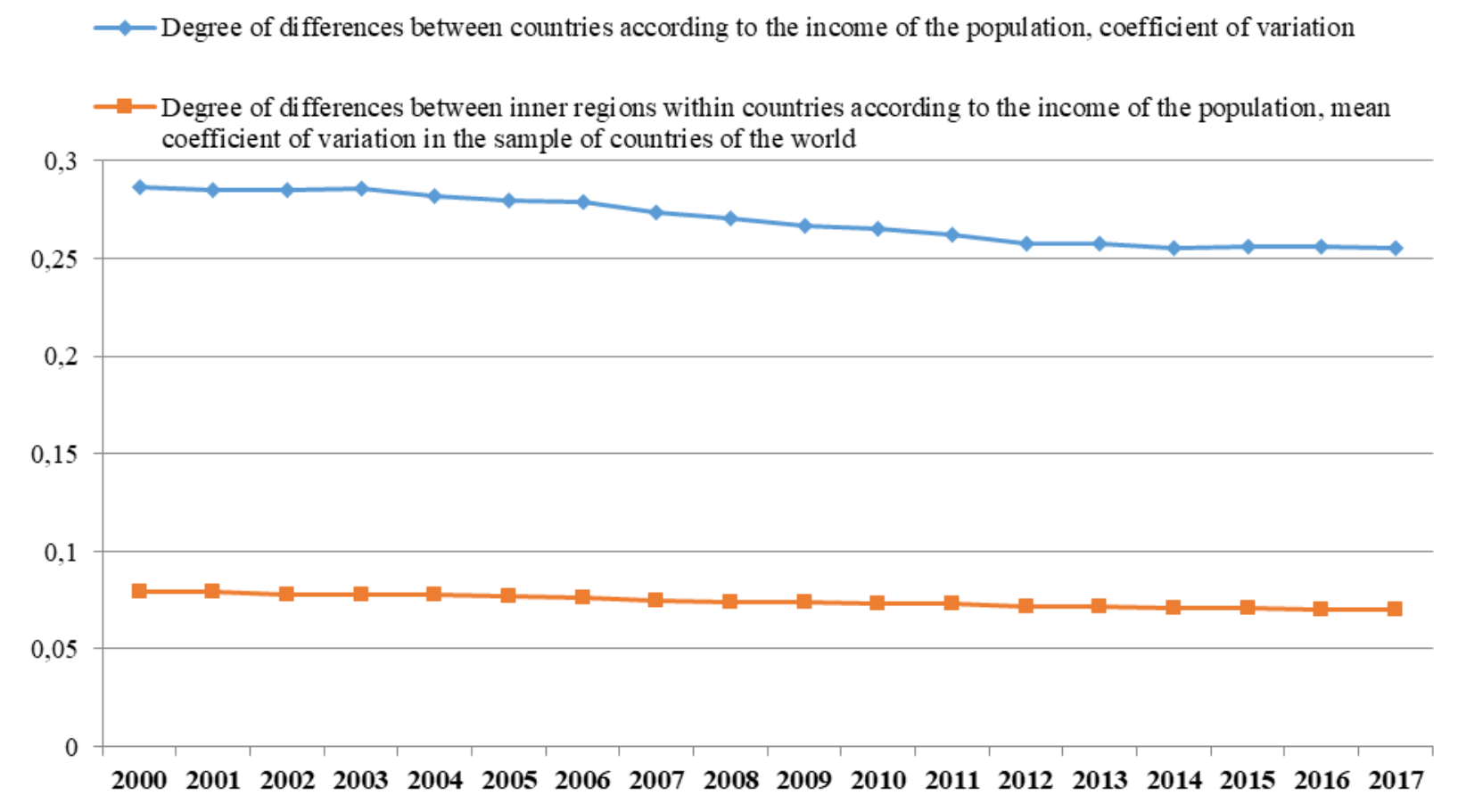

Figure 1. Comparison of the degree of economic differences in the world on the inter-country and the intra-country regional level, $n=132$ countries, 2000-2017

Source: elaborated by the authors according to the data of Table 1

Note: the name of the indicator under analysis in the data source is: Income index of Subnational Human Development Index (Radboud University 2020)

As the data of Table 1 and Figure 1 and 2 show, at the beginning of the $21^{\text {st }}$ century neither in the world generally nor in the European Union economic differences on the intra-country regional level were dominant above the inter-country differences. Though after 2015 in the EU the degree of economic differences on the intra-country regional level rose above the degree of economic differences on the inter-country level, i.e. inner regions within each individual EU country started differing in average from each other more than the EU countries between themselves. Yet, before 2015 the EU intra-country regional economic differences were also relatively high as compared to the inter-country economic differentiation - hence, this is the specific feature of the European Union. Besides, both the inter-country and intra-country regional economic differences in the EU countries are significantly lower than generally in the world (see Table 1, Figure 1 and 2). 
ENTREPRENEURSHIP AND SUSTAINABILITY ISSUES

ISSN 2345-0282 (online) http://jssidoi.org/jesi/

2021 Volume 8 Number 3 (March)

http://doi.org/10.9770/jesi.2021.8.3(6)

Make your research more visible, join the Twitter account of ENTREPRENEURSHIP AND SUSTAINABILITY ISSUES: @Entrepr69728810

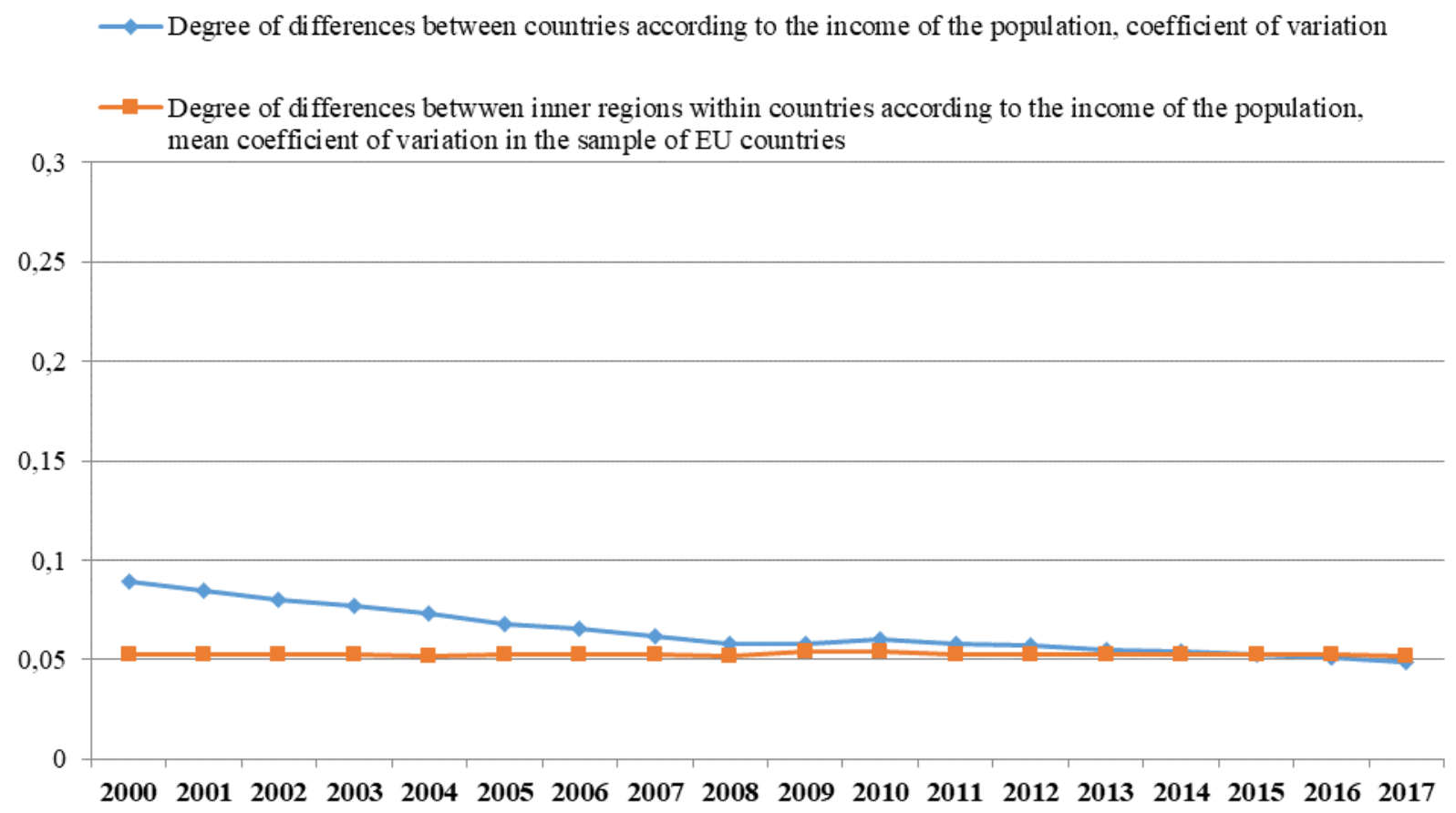

Figure 2. Comparison of the degree of economic differences in the European Union on the inter-country and the intra-country regional level, $n=26$ countries, 2000-2017

Source: elaborated by the authors according to the data of Table 1

Notes: 1) the name of the indicator under analysis in the data source is: Income index of Subnational Human Development Index (Radboud University 2020); 2) the sample of European Union countries includes those countries that were EU Member States in 2017 (except Luxembourg and Cyprus, which have no inner regions)

At the beginning of the analyzed period, the largest economic differences between regions within the country were observed in China - the coefficient of intra-country regional variation of the income of its population in 2000 was equal to 0.208 , but in 2017 it decreased significantly to 0.095 . In 2017, the "leader" of intra-country regional economic differences in the world was the Democratic Republic of Congo - the value of the coefficient of intra-country regional variation of the income of its population was equal to 0.196 (in 2000 this indicator was also relatively high for the Democratic Republic of Congo - 0.186). Regarding the opposite pole of intra-country regional economic differences, it should be noted that in 2000 , the "intra-country regional equality leader" was Barbados, with an inner regional variation coefficient of 0.011 according to the income of its population. In 2017, Serbia and Uruguay became the leaders: the coefficient of intra-country regional variation there was $0.005-$ the lowest in the sample of countries of the world.

Within the European Union, the "leader" of intra-country regional economic inequality is Slovakia, with a value of 0.100 of the inner regional coefficient of variation of the income of its population (in 2000 this indicator was also the highest in Slovakia - 0.102). In Slovakia, the capital region of Bratislava dominates strongly and stably, and the eastern region of the country lags stably too (Radboud University 2020). Sweden is the "leader" of intracountry regional economic equality in the European Union. Despite the fact that the capital region in Sweden also 
ENTREPRENEURSHIP AND SUSTAINABILITY ISSUES

ISSN 2345-0282 (online) http://jssidoi.org/jesi/

2021 Volume 8 Number 3 (March)

http://doi.org/10.9770/jesi.2021.8.3(6)

Make your research more visible, join the Twitter account of ENTREPRENEURSHIP AND SUSTAINABILITY ISSUES: @Entrepr69728810

dominates economically (Global Data Lab 2013-2019), the coefficient of intra-country regional variation of the income of the population in this country in 2017 was the lowest in EU - 0.030 (0.028 in 2000).

In search for the answer to the second research question, whether the decrease in the degree of economic differences on the inter-country level is determined by mainly the growth of capital regions, the authors further analyse empirical data just on the EU countries and their capital regions in the time period from 2000 to 2017.

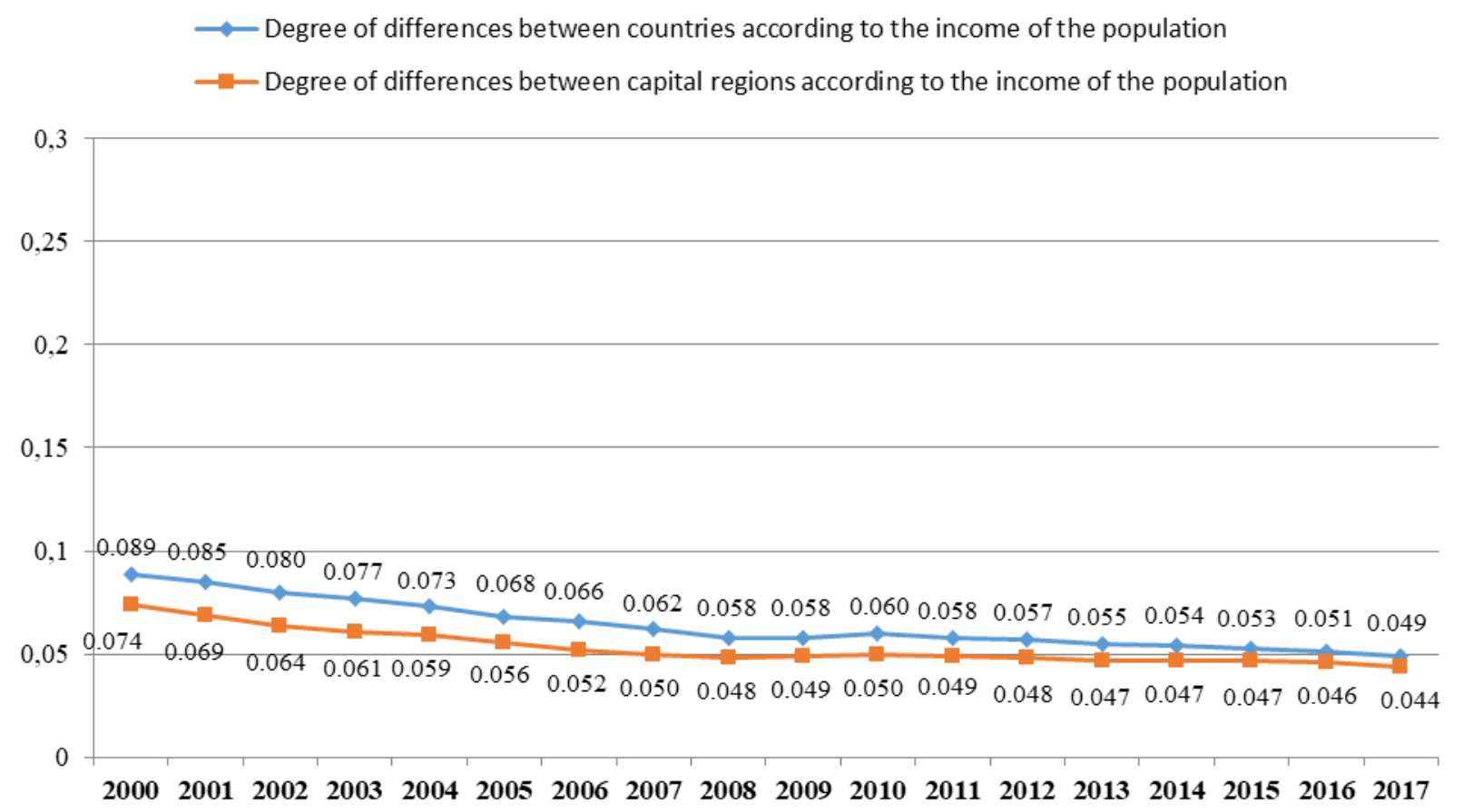

Figure 3. Comparison of the degree of economic differences in the EU on the inter-country and capital regions' level, coefficient of variation, $\mathrm{n}=26$ countries, 2000-2017

Source: calculated by the author and drawn according to the data of Radboud University 2020

Figure 3 shows the dynamics of economic differences between EU countries and their capital regions at the beginning of the $21^{\text {st }}$ century. Empirically and statistically appropriate answer to the question, whether (at least in the European Union) the differentiation process on the inter-country level is determined by growth exactly in the capital regions, is affirmative. The dynamics of the coefficient of variation shows that the degree of economic differences between EU capital regions during the period of 2000-2017 has been lower than between the EU countries. It means that, for instance, in the economic aspect, Latvia in general differs from Germany or Poland more than Riga from Berlin or Warsaw. However, this difference in the course of the $21^{\text {st }}$ century is diminishing (see Figure 3), indicating that in the present-day Europe there is gradually growing significance of non-capital regions, though the economic dominance and faster growth of capital regions in the European Union (supposedly in the world in general) is still prevalent (see also OECD 2016). 


\title{
ENTREPRENEURSHIP AND SUSTAINABILITY ISSUES
}

ISSN 2345-0282 (online) http://jssidoi.org/jesi/

2021 Volume 8 Number 3 (March)

http://doi.org/10.9770/jesi.2021.8.3(6)

Make your research more visible, join the Twitter account of ENTREPRENEURSHIP AND SUSTAINABILITY ISSUES: @Entrepr69728810

\section{Conclusions}

A comparison of the inter-country and intra-country regional economic differences in the world and European Union allowed the authors to conclude, that at the beginning of the $21^{\text {st }}$ century, neither the world nor the EU economic differences between countries' inner regions dominated over the inter-country economic differences. This allows the author to reject the first tested hypothesis, according to which economic differences between countries are often not so large as the economic differences between regions within these countries. However after 2015, the degree of the economic differences between inner regions of countries in the EU started exceeding intercountry economic differences, i.e., the inner regions within each individual EU country began to differ on average more than the EU countries themselves. However, even until 2015, the economic differences of the inner regions of the EU countries was relatively high in comparison with the economic differences between the whole countries, which is the specifics of the European Union. At the same time, both tinter-country and intra-country regional economic differences in EU countries are significantly lower than in the world as a whole.

Empirically justified answer to the question whether the decrease in inter-country economic differences in the European Union is determined by mostly the growth of capital regions is affirmative. It is supported by the dynamics of the coefficient of variation in the time period from 2000 to 2017, which shows that the degree of economic differences between the EU countries' capital regions is lower than between the EU countries in general. This difference gradually decreases, indicating that at the beginning of the $21^{\text {st }}$ century in the European Union there is growth of the economic significance of non-capital regions.

\section{References}

Atkinson, A.B. (1970). On the measurement of inequality. Journal of Economic Theory, 2, 244-63. https://doi.org/10.1016/0022$\underline{0531(70) 90039-6}$

\begin{abstract}
Berzins M. (2011). Iekšzemes migrācijas reǵionālās dimensijas Latvijā. [Regional dimensions of domestic migration in Latvia] Proceedings of the Latvian Academy of Sciences, A (3/4), 35-54. Retrieved September 11, 2020 from http://www.lasproceedings.lv/wpcontent/uploads/2020/12/LZA-Vestis-A-dala-2011.-gada-3.-un-4.-numurs.pdf
\end{abstract}

Boronenko, V., Mensikovs, V., \& Lavrinenko, O. (2014). The impact of EU accession on the economic performance of the countries' internal (NUTS 3) regions. Journal of Economics and Business, 32 (2), 313-341. Retrieved September 11 , 2020 from https://www.efri.uniri.hr/upload/Nastavnici\%20i\%20istrazivanja/Arhiva\%20Zbornika\%20radova/04-boronenko_mensikovs_lavrinenko2014-2-1420787428.pdf

Chatterji, M. (2014). Walter Isard and the role of Regional Science and Peace Science for the poor countries. International Regional Science Review, 37 (1), 96-106. https://doi.org/10.1177/0160017613484927

Drobishevkiy, S., Lugovoy, O., Astafyeva, Y., Polevoy, D., Kozlovskaya, A., Trunin, P., \& Lederman, L. (2005). Фaкmopbl экономического роста в регионах $Р \Phi$. [Factors of the Economic Growth in Regions of the RF] Moscow: IEPP.

Dunford, M. (2008). After the three Italies the (internally differentiated) North-South divide: analysing regional and industrial trajectories. Annales de Géographie, 664 (6). Retrieved September 11, 2020 from https://www.researchgate.net/publication/228621238 After the three Italies the internally differentiated NorthSouth_divide_Analysing_regional_and_industrial_trajectories

European Commission. (2011). Regions in the European Union - Nomenclature of territorial units for statistics NUTS 2010/EU-27. Luxembourg: Publications Office of the European Union. Retrieved September 11, 2020 from https://ec.europa.eu/eurostat/documents/3859598/5916917/KS-RA-11-011-EN.PDF

Eurostat. (2018). Eurostat Regional Yearbook 2018. Luxembourg: Publications Office of the European Union. 


\section{ENTREPRENEURSHIP AND SUSTAINABILITY ISSUES}

ISSN 2345-0282 (online) http://jssidoi.org/jesi/

2021 Volume 8 Number 3 (March)

http://doi.org/10.9770/jesi.2021.8.3(6)

Make your research more visible, join the Twitter account of ENTREPRENEURSHIP AND SUSTAINABILITY ISSUES: @Entrepr69728810

Gibbons, S., \& Vignoles, A. (2011) Geography, choice and participation in higher education in England. Regional Science and Urban Economics, 42 (1-2), 98-113. https://doi.org/10.1016/j.regsciurbeco.2011.07.004

Granberg, A. (1997). Regional science and new regional policy in Russia. In M. Chatterji (Ed.), Regional Science: Perspectives for the Future (pp. 248-262). London: Macmillan Press. Retrieved September 11, 2020 from https://link.springer.com/chapter/10.1007/978-1-349$\underline{25514-6 \_17}$

Howe, E., \& Stabler, J. (1989). Canada divided: the optimal division of an economy into regions. Journal of Regional Science, $29,191-211$. https://doi.org/10.1111/j.1467-9787.1989.tb01232.x

Hua, J., \& Gu, Ch. (2001). Economic analysis on regional economic difference. Geographical Research, 20 (3), $322-329$.

Iodchin, А. (2007). Эконометрическое моделирование межрегиональной конвергениии в России: автореферат диссертации. [Econometric Modelling of the Regional Convergence in Russia: Resume of the Dissertation] Moscow: Moscow State University.

Retrieved September 11, 2020 from https://www.dissercat.com/content/ekonometricheskoe-modelirovanie-mezhregionalnoi-konvergentsiiv-rossii

Isard, W. (1960). Methods of Regional Analysis: Introduction to Regional Science. Cambridge, MA: MIT Press and John Wiley.

Isard, W. (1975). Introduction to Regional Science. New York: Prentice Hall.

Kanbur, R., \& Venables, A.J. (2005). Spatial inequality and development. In R. Kanbur \& A.J. Venables (Eds.), Spatial Inequality and Development (pp. 115-132). Oxford: Oxford University Press. Retrieved September 11, 2020 from https://global.oup.com/academic/product/spatial-inequality-and-development-9780199278633?cc=lv\&lang=en\&

Kanbur, R., Venables, A.J., \& Wan, G. (2006). Spatial Disparities in Human Development: Perspectives from Asia. United Nations Press. Retrieved September 11, 2020 from https://collections.unu.edu/view/UNU:2547

Kanbur, R., \& Zhang, X. (2005). Fifty years of regional inequality in China: a journey through central planning, reform and openness. Review of Development Economics, 9 (1), 87-106. https://doi.org/10.1111/j.1467-9361.2005.00265.x

Karwat-Wozniak, B. (2011). Regional differentiation in the socio-economic development conditions of the agriculture in Poland. Economics \& Sociology, 4 (2), 11-25. Retrieved September 11, 2020 from https://www.economics-sociology.eu/files/E\&S_4_2_guest.pdf

Kim, S. (1998). Economic integration and convergence: U.S. regions, 1840-1990. Journal of Economic History, 58, 659-683. https://doi.org/10.1017/S0022050700021112

Kim, S. (2008). Spatial inequality and economic development: theories, facts and policies. Working Paper No. 16. Washington: The World Bank. Retrieved September 11, 2020 https://openknowledge.worldbank.org/handle/10986/28050?locale-attribute=es

Knight, J., Shi, L., \& Renwei, Zh. (2006). Divergent means and convergent inequality of incomes among the provinces and cities of urban China. In R. Kanbur, A.J. Venables, \& G. Wan (Eds.), Spatial Disparities in Human Development: Perspectives from Asia (pp. 126-144). United Nations Press. Retrieved September 11, 2020 from https://collections.unu.edu/view/UNU:2547

Kolaríkova, J., Dvoulety, O., \& Kolarík, P. (2018). Economic performance of the NUTS III regions in the Czech Republic in the context of entrepreneurship subsidies from the EU structural funds. Journal of Economics and Business (Proceedings of Rijeka Faculty of Economics), 36 (1), 129-153. https://doi.org/10.18045/zbefri.2018.1.129

Kovacs, Z. (2004). Socio-economic transition and regional differentiation in Hungary. Geographical Bulletin, LIII (1-2). Retrieved September 11, 2020 from https://www.researchgate.net/publication/228962218_Socioeconomic transition and regional differentiation in Hungary

Krauklis, A. (2000). Living with diversity in Latvia: people, nature and cultural landscape. Folia Geographica, 8, 1-14. Retrieved September 11, 2020 from

https://www.geo.lu.lv/fileadmin/user_upload/LU.LV/Apaksvietnes/Fakultates/www.gzzf.lu.lv/Folia_Geographica/Geografiski_raksti_VIII. pdf 


\section{ENTREPRENEURSHIP AND SUSTAINABILITY ISSUES}

ISSN 2345-0282 (online) http://jssidoi.org/jesi/

2021 Volume 8 Number 3 (March)

http://doi.org/10.9770/jesi.2021.8.3(6)

Make your research more visible, join the Twitter account of ENTREPRENEURSHIP AND SUSTAINABILITY ISSUES: @Entrepr69728810

Krisjane, Z., \& Bauls, A. (2007). Migrācijas plūsmu reǵionālās iezīmes Latvijā. [Regional features of migration flows in Latvia] Paaudžu nomaiṇa un migrācija Latvijā (Stratēgiskās analīzes komisijas zinātniski pētnieciskie raksti), 4 (15), 130-143.

Kule, L., Krisjane, Z., \& Berzins, M. (2010). Rhetoric and reality of pursuing territorial cohesion in Latvia. In N. Adams, G. Cotella, \& R. Nunes (Eds.), Territorial Development, Cohesion and Spatial Planning: Building on EU Enlargement (pp. 586-645). London: Routledge.

Kuttor, D. (2009). Territorial inequalities in Central Europe: spatial analysis of the Visegrad countries. Romanian Review of Regional Studies, V (1). Retrieved September 11, 2020 from https://core.ac.uk/download/pdf/27060466.pdf

Lavrinovica, I., \& Lavrinenko, O. (2011). Iedzīvotāju ienākumu diferenciācija Latvijas regionos. [Income Differentiation of the Population in Latvia's Regions] Daugavpils: Publishing House of Daugavpils University “Saule”. Retrieved September 11, 2020 from https://www.researchgate.net/publication/299505811_Iedzivotaju_ienakumu_diferenciacija_Latvijas_regionos

Lavrinovich, I., Lavrinenko, O., \& Jefimovs, N. (2012). Sustainable development, economic growth and differentiation of incomes of Latvian population. Journal of Security and Sustainability, 2 (1), 33-39. https://doi.org/10.9770/jssi/2012.2.1(3)

Lubrano, M. (2017). Lorenz curves, the Gini coefficient and parametric distributions. The Econometrics of Inequality and Poverty. Retrieved September 11, 2020 from http://www.vcharite.univ-mrs.fr/PP/lubrano/cours/Lecture-4.pdf

OECD. (2011). Regional economic disparities. In, OECD Regions at a Glance 2011 (pp. 40-45). Paris: OECDPublishing, Retrieved September 11, 2020 from https://www.oecd-ilibrary.org/docserver/reg_glance-2011-11en.pdf?expires=1613197250\&id=id\&accname=guest\&checksum=EB92DDDDE7D33EDE0B812E175E373390

OECD. (2013). OECD Regions at a Glance 2013. Paris: OECD Publishing. Retrieved September 11, 2020 from https://www.oecdilibrary.org/urban-rural-and-regional-development/oecd-regions-at-a-glance-2013_reg_glance-2013-en

OECD. (2016). OECD Regions at a Glance 2016. Paris: OECD Publishing. Retrieved September 11, 2020 from http://www.oecd.org/regional/oecd-regions-at-a-glance-19990057.htm

Okuneviciute-Neverauskiene, L., Danileviciene, I. \& Tvaronaviciene, M. (2020). Assessment of the factors influencing competitiveness fostering the country's sustainability. Economic Research-Ekonomska Istraživanja, 33(1), 1909-1924. https://doi.org/10.1080/1331677X.2020.1763821

Paas, T., \& Schlitte, F. (2006). Regional income inequality and convergence processes in the EU-25. ERSA conference papers, European Regional Science Association. Retrieved September 11, 2020 from http://www-sre.wu-wien.ac.at/ersa/ersaconfs/ersa06/papers/229.pdf

Prakash, R., Garg, P. (2019). Comparative assessment of HDI with Composite Development Index (CDI). Insights into Regional Development, 1(1), 58-76. https://doi.org/10.9770/ird.2019.1.1(5)

Rivza, B. (Ed.) (2018) Zināšanu ekonomika Latvijas lauku un regionu dzīvotspējai. [Knowledge Economy for the Viability of Latvia's Countryside and Regions] Jelgava: Publishing House of Jelgava. Retrieved September 11, 2020 from https://llufb.llu.lv/LLUgramatas/Monografija Zinasanu ekonomika Latvijas lauku regionu dzivotspejai.pdf

Rodriguez-Pose, A., \& Sanchez-Reaza, J. (2005). Economic polarization through trade: trade liberalization and regional growth in Mexico. In R. Kanbur, A.J. Venables (Eds.), Spatial Inequality and Development (pp. 152-179). Oxford: Oxford University Press. Retrieved September 11, 2020 from https://collections.unu.edu/view/UNU:2547

Ruitebeek, H. (1996). Distribution of ecological entitlements: implications for economic security and population movement. Ecological Economics, 17, 49-64. https://doi.org/10.1016/0921-8009(95)00103-4

Radboud University. (2020). The Global Data Lab, Sub-national HDI database. Retrieved September 11, 2020 from https://hdi.globaldatalab.org/areadata/shdi/

Sala-i-Martin, X. (1995). The classical approach to convergence analysis. Economics Working Paper No. 117. Yale: Yale University, Universitat Pompeu Fabra. Retrieved September 11, 2020 from https://ideas.repec.org/p/upf/upfgen/117.html 
ENTREPRENEURSHIP AND SUSTAINABILITY ISSUES

ISSN 2345-0282 (online) http://jssidoi.org/jesi/

2021 Volume 8 Number 3 (March)

http://doi.org/10.9770/jesi.2021.8.3(6)

Make your research more visible, join the Twitter account of ENTREPRENEURSHIP AND SUSTAINABILITY ISSUES: @Entrepr69728810

Sala-i-Martin, X. (1996). Regional cohesion: evidence and theories of regional growth and convergence, European Economic Review, 40(6), 1325-1352. https://doi.org/10.1016/0014-2921(95)00029-1

Stankevics, A., Ignatyeva, S., \& Menshikovs, V. (2014). Higher education's contribution to economic performance and innovativeness in Latvia: exploratory research. Economic Annals, 202(59), 7-41. https://doi.org/10.2298/EKA1402007S

Styme S., \& Jackson T. (2000). Intra-generational equity and sustainable welfare: a time series analyses for the UK and Sweden. Ecological Economics, 33, 219-236. https://doi.org/10.1016/S0921-8009(99)00144-5

Tvaronaviciene, M. (2018). Towards efficient policy making: Forecasts of vulnerability to external global threats. Journal of Security and Sustainability Issues, 7 (3). https://doi.org/10.9770/jssi.2018.7.3(18)

Ullman E. (1958) Regional development and the geography of concentration. Papers and Proceedings of the Regional Science Association, 4, 179-198. https://doi.org/10.1111/j.1435-5597.1958.tb01629.x

UNDP. (2020). United Nations Development Programme, Human Development Index (HDI). Retrieved on September 11, 2020, from http://hdr.undp.org/en/content/human-development-index-hdi

Vera KOMAROVA is Dr. oec., Leading Researcher at the Social Investigations Centre of Institute of Humanities and Social Sciences of Daugavpils University (Latvia). She has status of the external expert of the COST Association (Brussel). Her research interests: industrial clusters, regional economics, sustainable territory development.

ORCID ID: 0000-0002-9829-622X

Natalya Selivanova-FYODOROVA is PhD in Economics and Entrepreneurship, Lecturer at the RISEBA University of Applied Sciences (Latvia). Her research interests: macroeconomics, differentiation of territories, quantitative research methods.

ORCID ID: 0000-0001-8561-4869

Oksana RUZA is Dr. oec., Docent, Researcher at the Social Investigations Centre of Institute of Humanities and Social Sciences of Daugavpils University (Latvia). Her research interests: regional economics, industrial economics, finances.

ORCID ID: 0000-0002-6194-3841

Jerzy KAZMIERCZYK is PhD, Assistant Professor at the Poznan University of Economics and Business (Poland), Member of the Presidium of Research Council of Polish Economic Society, and Member of the Regional Labor Market Board at Lubuskie Marshal's Office. His research interests: labor market, HRM, banking, macroeconomics.

ORCID ID: 0000-0002-5976-0210

Iluta ARBIDANE is Dr, oec., Dean of the Faculty of Economics and Management of Rezekne Academy of Technologies (Latvia). Her research interests: transport, new technologies, territory development.

ORCID ID: 0000-0002-9762-3874

Copyright (C) 2021 by author(s) and VsI Entrepreneurship and Sustainability Center

This work is licensed under the Creative Commons Attribution International License (CC BY).

http://creativecommons.org/licenses/by/4.0/

cC) (i) Open Access 